\title{
LAYANAN PENGUASAAN KONTEN DENGAN TEKNIK MODELING TERHADAP KECERDASAN EMOSIONAL SISWA SMP DI KOTA BENGKULU
}

\author{
Bernadine Lorena Yanwar, I Wayan Dharmayana, Vira Afriyati \\ Prodi Bimbingan dan Konseling Fakultas Keguruan Ilmu Pendidikan \\ Universitas Bengkulu \\ bernadinelorena@gmail.com,dharmayana@unib.ac.id,vira_afriyati@unib.ac.id
}

\begin{abstract}
ABSTRAK
Penelitian ini bertujuan mengetahui pengaruh layanan penguasaan konten dengan menggunakan teknik pemodelan terhadap kecerdasan emosional siswa. Desain menggunakan one group pre-test post test design. Sampel terdiri atas tiga puluh siswa kelas VIII C kota SMP Negeri 11 Bengkulu. Instrumennya adalah kuesioner, Uji-coba menghasilkan 73 item dengan $\alpha=0,89$ ('sangat tinggi'). Pada pre-test, rerata kecerdasan emosional siswa adalah 168,26 ('sedang'). Perlakuan terdiri atas penjelasan, praktik dan kegiatan tambahan selama 5 pertemuan. Pada post test, reratanta adalah 195,42 ('tinggi'). Uji hipotesis dengan uji-t menunjukkan bahwa $\mathrm{t}=-27.161$ ( $\mathrm{p}<0,05)$. Dengan demikian, $\mathrm{H}_{0}$ ditolak sementara $\mathrm{H}_{1}$ diterima. Artinya ada pengaruh signifikan layanan penguasaan konten dengan menggunakan teknik pemodelan pada kecerdasan emosional siswa kelas VIII C SMP Negeri 11 Bengkulu. Hasil penelitian menunjukkan sejumlah implikasi terhadap teori dan praktik.
\end{abstract}

Kata kunci: layanan penguasaan konten, teknik modeling, kecerdasan emosional

\section{THE EFFECT OF CONTENT MASTERY SERVICE BY USING MODELING TECHNIQUE ON THE EMOTIONAL INTELLIGENCE OF THE STUDENTS OF SMP KOTA BENGKULU}

\begin{abstract}
The research aimed to find out the effect of content mastery service by using modeling technique on students' emotional intelligence. A one-group pre-test post test design was employed. The sample consisted of thirty students of class VIII C of SMP Negeri 11 Bengkulu town. The instrument was a questionnaire, Try-out yielded 73 items with $\alpha=0.89$ ('very high'). At the pre-test, the students' emotional intelligence average was 168.26 ('moderate'). The treatment comprised of explanation, practice and additional activities for 5 sessions. At the post test, their average was 195.42 ('high'). Hypothesis testing by t-test showed that $\mathrm{t}=-27.161(\mathrm{p}<0.05)$. Thus, $\mathrm{H}_{0}$ was rejected while $\mathrm{H}_{1}$ was accepted. It means that there was a significant effect of content mastery service by using modeling technique on the emotional intelligence of the students of class VIII C SMP Negeri 11 Bengkulu town. The result suggests some implications for theory and practice.
\end{abstract}

Keywords: content mastery service, modeling technique, emotional intelligence 


\section{Pendahuluan}

Kecerdasan emosional merupakan salah satu faktor penting yang menunjang kehidupan seseorang. Kecerdasan emosional membawa dampak khususnya bagi individu yang memiliki kecerdasan emosional yang tinggi. Goleman (1996: 44) menyebutkan bahwa kecerdasan emosional jauh lebih berperan dalam kesuksesan hidup daripada kecerdasan intelektual. Goleman juga memperlihatkan bahwa kecerdasan intelektual (IQ) hanya menyumbang 20\% bagi kesuksesan, sedangkan $80 \%$ adalah sumbangan faktor kekuatan-kekuatan lain, diantaranya adalah kecerdasan emosional atau Emotional Quotient (EQ) yakni kemampuan memotivasi diri sendiri, mengatasi frustasi, mengontrol desakan hati, mengatur suasana hati (mood), berempati serta kemampuan bekerja sama.

Di beberapa daerah di Indonesia telah terjadi peristiwa yang memilukan yaitu ada seorang siswa SMP di Serang dikeroyok 15 teman sekelasnya (Topmedia, 09 September 2016); 3 orang siswa SMP merampok dan membunuh temannya dan membuang jasad temannya ke jurang (Kompas, 23 November 2016); seorang siswa SMP membunuh temannya karena kerap di bully (Okezone, 13 Oktober 2015); seorang siswa SMP yang membunuh mantan kekasih dengan palu lantaran ingin memiliki HP dan cemburu (Merdeka, 02 September 2015) dan siswa SMP yang menabrakkan pacarnya ke kereta karena minta dinikahi (MetroTV, 30 Januari 2016). Beberapa peristiwa di atas merupakan kasus tindak kekerasan yang dilakukan oleh remaja yang tidak dapat mengendalikan emosi dengan baik.

Masa remaja adalah masa peralihan antara masa kanak-kanak ke masa dewasa yang ditandai dengan perubahan fisik, sosial dan emosional. Menurut Hurlock (1980: 206), remaja berasal dari kata latin adolescence yang berarti tumbuh. Lazimnya masa remaja dimulai pada saat anak secara seksual menjadi matang dan berakhir pada saat ia mencapai usia matang. Awal masa remaja berlangsung kira-kira dari usia 13 tahun sampai usia 16 atau 17 tahun.

Melianasari (2016: 311) mengatakan bahwa pada usia remaja awal, perkembangan emosi remaja menunjukkan sifat yang sangat sensitif dan reaktif yang sangat kuat terhadap berbagai peristiwa atau situasi sosial, emosinya bersifat negatif dan temperamental seperti mudah tersinggung, marah, dan mudah sedih/murung.

Fenomena yang terjadi di SMP N 11 yaitu siswa masih belum bisa mengontrol emosinya, suasana hati para siswa masih 
sering berubah mendadak, siswa masih sering mengolok-olok, bersikap agresif, dan bertemperamen tinggi, siswa masih ada yang suka menyendiri, bermuka muram dan kurang bersemangat, sikap siswa yang masih kasar kepada teman yang lain, siswa masih belum bisa berpikir jernih mana tindakan yang pantas dilakukan dan mana yang tidak seperti memakai topi di dalam kelas, masih memiliki rasa cemburu, iri kepada teman yang lain, siswa yang bertengkar dengan temanya padahal masih ada guru di dalam kelas, serta siswa yang ketahuan membawa telepon genggam dan memainkannya selama proses pembelajaran sedang berlangsung. Menurut Nurnanigsih (2011: 269), permasalahan lain dalam hal perhatian dan pikiran yaitu banyak diantara siswa yang tidak mampu memusatkan perhatian dengan baik atau duduk tenang, seringkali melamun, bertindak tanpa berpikir, bersikap terlalu tegang sehingga tidak bisa berkonsentrasi dalam belajar, sering mendapatkan nilai buruk di sekolah serta tidak mampu membuat pikiran menjadi tenang.

Menurut Gottman, Individu yang memiliki kecerdasan emosional yang tinggi, dapat menjadi lebih terampil dalam menenangkan dirinya, lebih terampil dalam memusatkan perhatian, lebih baik dalam berhubungan dengan orang lain, lebih cakap dalam memahami orang lain dan untuk kerja akademis di sekolah lebih baik (Nurnaningsih, 2011: 269).

Memiliki kecerdasan emosional yang tinggi akan membuat remaja mampu berkomunikasi dan berhubungan baik dengan orang lain, mampu mengelola emosi, sehingga tahu bagaimana harus bersikap, bagaimana mengekspresikan perasaan sesuai dengan situasi dan kondisi yang sedang dihadapi. Untuk dapat meningkatkan serta mengembangkan kecerdasan emosional siswa, perlu disusun program yang tepat. Salah satu program yang dapat dilakukan adalah program layanan penguasaan konten yang dapat meningkatkan kecerdasan emosional siswa. Teknik yang digunakan adalah teknik modeling.

Menurut Prayitno (2004: 2) layanan penguasaan konten adalah "layanan bantuan kepada individu (sendiri-sendiri ataupun dalam kelompok) untuk menguasai kemampuan atau kompetensi tertentu melalui kegiatan belajar". Kompetensi disini terkait koten yang hendak diajarkan. Teknik modeling dilakukan dengan contoh perilaku seseorang individu atau kelompok (model) sebagai stimulus terjadinya pikiran, sikap, dan perilaku yang serupa di pihak pengamat (Sutanti, 2015: 192) sehingga teknik ini mampu membantu siswa dalam 
merubah sikap dan perilaku yang negatif yang telah terjadi dalam kehidupannya.

Langkah-langkah dalam modeling menurut Bandura (dalam Feist Jess \& Feist Gregory J., 2010: 204) yaitu (1)Perhatian, yang artinya kita memperhatikan seperti apa perilaku atau tindakan - tindakan yang dilakukan oleh orang yang akan ditiru, (2)Representasi, dilakukan setelah mengamati perilaku yang akan ditiru dan menyimpan setiap informasi yang didapat dalam ingatan, kemudian mengeluarkan ingatan tersebut saat diperlukan, (3)Produksi perilaku, hal ini dapat menegaskan bahwa kemampuan motorik seseorang juga mempengaruhi seseorang meniru suatu perilaku yang dilihat baik secara keseluruhan atau hanya sebagian. Setelah memperhatikan seorang model dan mempertahankan apa yang telah diobservasi, kemudian kita memproduksi perilaku tersebut, (4)Motivasi (penguatan), penguatan ini sangat penting, karena dapat menentukan seberapa mampu melakukan peniruan tersebut. Penguatannya dapat memacu keinginan individu tersebut untuk memenuhi tahapan belajarnya.

\section{Metode Penelitian}

Jenis penelitian ini termasuk penelitian Pre-eksprerimen. dengan onegroup pretest-posttest design. Pengambilan sampel dilakukan secara purposive sampling dengan pertimbanganpertimbangan tertentu atau penentuan sampel untuk tujuan tertentu (Riduwan, 2013: 20). Sampel dalam penelitian ini adalah kelas VIII C yang berjumlah 31 siswa, yang diambil dengan pertimbangan bahwa emosi siswa yang masih meledakledak, masih ada siswa yang bertengkar satu sama lain, kurang bersemangat, kasar terhadap yang lain, banyak siswa yang egois dan mementingkan kepentingan sendiri daripada kepentingan orang lain.

Untuk mengetahui tingkat kecerdasan emosional siswa, digunakan angket/kuesioner. Data dianalisis secara statistik dengan menggunakan Statistical Packages for Sosial Science (SPSS) for Windows Release 16.00. Uji kelayakan instrumen dilaksanakan dengan pengujian validitas dan pengujian reliabilitas instrumen.

\section{Hasil dan Pembahasan}

Hasil penelitian mendekripsikan, dari subjek yang berjumlah 31 orang siswa, dapat diketahui bahwa siswa dengan kategori rendah memiliki presentase $45.2 \%$, siswa dengan kategori sedang memiliki presentase $22.6 \%$, siswa dengan kategori tinggi memiliki presentase $9.7 \%$, dan siswa dengan kategori sangat tinggi memiliki 
presentase $22.6 \%$. Hasil dapat dilihat di tabel 1.

Tabel 1.

Distribusi Frekuensi Tingkat Kecerdasan Emosional Sebelum Perlakuan

\begin{tabular}{ccc}
\hline Kategori & $\begin{array}{c}\text { Jumlah } \\
\text { siswa }\end{array}$ & $\%$ \\
\hline Sangat tinggi & 7 & $22,6 \%$ \\
Tinggi & 3 & $9,7 \%$ \\
Sedang & 7 & $22,6 \%$ \\
Rendah & 14 & $45,2 \%$ \\
Sangat rendah & 0 & 0 \\
\hline Total & 31 & 100 \\
\hline
\end{tabular}

Hasil posttest menunjukkan, dari subjek yang berjumlah 31 orang siswa, siswa dengan kategori rendah memiliki presentase $6.5 \%$, siswa dengan kategori tinggi memiliki presentase $38.7 \%$, dan siswa dengan kategori sangat tinggi memiliki presentase $54.8 \%$. Hasil dapat dilihat pada Tabel 2 .

Tabel 2.

Distribusi Frekuensi Tingkat Kecerdasan Emosional Setelah Perlakuan

\begin{tabular}{ccc}
\hline Kategori & $\begin{array}{c}\text { Jumlah } \\
\text { siswa }\end{array}$ & $\%$ \\
\hline Sangat tinggi & 17 & $54,8 \%$ \\
Tinggi & 12 & $38,7 \%$ \\
Sedang & 2 & $6,5 \%$ \\
\hline Total & 31 & 100
\end{tabular}

Tabel 2 menunjukkan dari 31 siswa dapat diketahui bahwa mean sebelum perlakuan yaitu sebesar 168.26 dan mean setelah perlakuan yaitu sebesar 195.42, standar deviasi sebelum perlakuan yaitu sebesar 25.426 dan standar deviasi setelah perlakuan yaitu sebesar 13.540, skor maksimum sebelum perlakuan yaitu sebesar 207 dan skor maksimum setelah perlakuan yaitu sebesar 217, skor minimum sebelum perlakuan yaitu sebesar 136 dan skor minimum setelah perlakuan yaitu sebesar 169.

Tabel 3.

Hasil Pre-Test dan Post-Test Kecerdasan Emosional Siswa

\begin{tabular}{|c|c|c|c|}
\hline & & Pretest & Posttest \\
\hline $\mathrm{N}$ & Valid & 31 & 31 \\
\hline & Missing & 0 & 0 \\
\hline $\mathrm{M}$ & & 168.26 & 195.42 \\
\hline & Deviation & 25.426 & 13.540 \\
\hline & num & 136 & 169 \\
\hline & mum & 207 & 217 \\
\hline
\end{tabular}

Untuk menguji hipotesis dalam penelitian ini, peneliti menggunakan uji $t$ test dengan menggunakan software statistical packages for social science (SPSS 16), dengan uji Paired Sample Test karena akan membandingkan atau melihat perbedaan kedua hasil rata-rata hasil pretest dan hasil posttest, dan untuk melihat 
apakah terdapat pengaruh layanan penguasaan konten dengan teknik modeling terhadap kecerdasan emosional siswa kelas VIII C SMP Negeri 11 Kota Bengkulu.

Tabel 4.

Uji t

\begin{tabular}{ccc}
\hline $\mathrm{t}$ & $\mathrm{df}$ & $\begin{array}{c}\text { Sign. (2- } \\
\text { tailed) }\end{array}$ \\
\hline-27.161 & 30 & .000 \\
\hline
\end{tabular}

Dari penyajian Tabel 4, dapat dilihat bahwa nilai $\mathrm{t}(30)=-27.161$ dengan Signifikansi $\quad(2$-tailed $) \quad 0.000 \quad(\mathrm{p}<0.05)$, dengan demikian dapat disimpulkan bahwa terdapat perbedaan yang signifikan antara kecerdasan emosional sebelum (dengan mean $=168.26)$ dan setelah layanan penguasaan konten (mean $=195.42$ ). Mean setelah pelaksanaaan layanan penguasaan konten dengan teknik modeling lebih tinggi dibanding mean sebelum layanan. Artinya ada pengaruh layanan penguasaan konten dengan teknik modeling terhadap kecerdasan emosional.

\section{Kesimpulan}

Berdasarkan hasil penelitian yang dikemukakan pada pembahasan sebelumnya, maka dapat disimpulkan bahwa terdapat pengaruh layanan penguasaan konten dengan teknik modeling terhadap kecerdasan emosional siswa.
Berdasarkan simpulan di atas, maka hasil penelitian ini menyarankan kepada pihak terkait sebagai berikut: (1) Kepada guru bimbingan dan konseling di SMP Negeri 11 Kota Bengkulu diharapkan untuk tetap memberikan kegiatan pelayanan BK, walaupun tidak tersedianya jam BK, (2) Kepada siswa, dengan diberikan layanan penguasaan konten dengan teknik modeling, diharapkan siswa meningkatkan kecerdasan emosionalnya, karena akan sangat bermanfaat tidak hanya untuk diri sendiri, melainkan juga untuk orang lain dalam bersosialisasi, (3) Kepada penelitian selanjutnya disarankan untuk menggunakan jenis layanan bimbingan dan konseling yang lain dalam meningkatkan kecerdasan emosional siswa.

\section{Daftar Pustaka}

Feist, Jess. Feist, Gregory, J. (2010). Teori Kepribadian Theories of Personality. Jakarta: Salemba Humanika.

Gilang. (2016). Topmedia. Siswa SMP di Serang Dikeroyok 15 Teman Sekelasnya. 09, September 2016.

Goleman, Daniel. (1996). Emotional Intelligence Kecerdasan Emosional Mengapa EI Lebih Penting Daripada IQ. Jakata: PT Gramedia Pustaka Utama. 
Hurlock, Elizabeth, B. (1980). Psikologi Perkembangan: Suatu Pendekatan Sepanjang Rentang Kehidupan. Edisi Kelima. Jakarta: Erlangga.

Leandha, M. (2016). Kompas. Merampok dan Membunuh, 3 Siswa SMP Buang Jasad Temannya ke Jurang. 23, November 2016.

Melianasari, Dewi. (2016). "Penerapan Layanan Bimbingan Kelompok Melalui Teknik Permainan Simulasi dan Untuk Meningkatkan Kecerdasan Emosi Siswa", Jurnal Pedagogia, Vol.14, No.2, 311-317.

Ningrum, D, A. (2015). Merdeka. Gara-gara Cemburu dan HP, Siswa SMP Bunuh Mantan Kekasih dengan Palu. 02, September 2015.

Nurnaningsih, (2011). "Bimbingan Kelompok Untuk Meningkatkan Kecerdasan Emosional Siswa". Jurnal Penelitian Pendidikan, Edisi Khusus No.1, Agustus 2011, ISSN 1412-565X, 268-278.

Prayitno. (2004). L.1-L.9. Padang: Universitas Negeri Padang.

Rofahan, A. (2016). MetroTV. Minta Dinikahi, Alasan Siswa SMP Tabrakan Pacar ke Kereta. 30, Januari 2016.

Sutanti, Tri. (2015). Efektivitas Teknik Modeling untuk Meningkatkan Empati Mahasiswa Prodi BK Universitas Ahmad Dahlan. Jurnal Psikologi Pendidikan \& Konseling. Vol.1, No.2, 188-198.

Sukiswanti, P. (2015). Okezone. Di-Bully, Siswa SMP Ini Bunuh Temannya. 13, Oktober 2015. 